\title{
Life cycle of Phoebemima ensifera Tippmann (Coleoptera, Cerambycidae)
}

\author{
Robin O. S. Clarke ${ }^{1} \&$ Sonia Zamalloa ${ }^{1}$
}

${ }^{1}$ Hotel Flora and Fauna, Casilla 2097, Santa Cruz de la Sierra, Bolivia. hotelfandf@hotmail.com

\begin{abstract}
Life cycle of Phoebemima ensifera Tippmann (Coleoptera, Cerambycidae). An account of host plant selection, larval development and behaviour, and behaviour of adult Phoebemima ensifera. Illustrations of the host plant, plant parts, larva, pupa, and adult are provided.
\end{abstract}

KEYWORDS. Biology; ethology; Hemilophini; Lamiinae.

RESUMO. Ciclo vital de Phoebemima ensifera Tippmann (Coleoptera, Cerambycidae). Descreve-se a seleção da planta hospedeira, desenvolvimento e comportamento larval, e comportamento do adulto de Phoebemima ensifera. Ilustrações da planta-hospedeira, larva, pupa e adultos são fornecidas.

PALAVRAS-CHAVE. Biologia; etologia; Hemilophini; Lamiinae.

Monné \& Hovore (2006) have recorded the Western Hemisphere tribe Hemilophini Thomson, 1868 from Kansas State, USA to Argentina. However, it is primarily a Neotropical tribe: three genera (five species) recorded from the USA (Kansas, South Carolina to Florida), 16 genera (36 species) from Mexico, 45 genera (110 species) from Central America, five genera (23 species) from the Caribbean, and 99 genera (333 species) from South America (of which eigth genera and 17 species have been recorded from Uruguay and Argentina, and none from Chile).

Given that tribe the Hemilophini contains a multitude of species (nearly 500) with a large geographical range the knowledge of their biology and host plants is very limited. The first record, Bondar (1938), briefly outlines the damage done by the larva of Gagarinia borgmeieri (Bondar,1938); the second, Molinari (1942), gives a short account of the biology of Apagomerella versicolor (Boheman, 1859). Duffy (1960) in his monograph of the immature stages of the Neotropical Cerambycidae further references the host plants of two species of Phoebe Audinet-Serville, 1835. Di Iorio et al. (1998) refer to the larval activity of Zeale nigromaculatata (Klug, 1829). Most recently, Monné (2002), catalogues the present knowledge with references to the host plants of three further species: Adesmus nevisi (Gounelle, 1909), Calocosmus speciosus Chevrolat, 1862, and Eranina argentina (Bruch, 1911).

Based on observations of host plants, immatures and adults in the field and laboratory we describe, for the first time, the life cycle of Phoebemima ensifera Tippmann, 1960. Photographs of the host plant, girdled branches, larva, pupa, and adults are given.

The acronyms used in the text are as follows: Museu de Zoologia, Universidade de São Paulo, São Paulo, Brasil (MZSP); Robin Clarke/Sonia Zamalloa private collection, Hotel Flora \& Fauna, Buena Vista, Santa Cruz, Bolivia (RCSZ).

\section{MATERIALAND METHODS}

The study was undertaken in Bolivia, Department of Santa Cruz, at the Hotel Flora \& Fauna, 17²9'96"S/63³9'13"W, $430 \mathrm{~m}, 5 \mathrm{~km}$ SE of Buena Vista. This hilly locality lies in disturbed transition forest (Semideciduous Chiquitano Forest and Tropical Humid Forest), $16 \mathrm{~km}$ from the foot of the eastern Cordillera of the Andes.

Clarke \& Sagot (1996) state that: "meteorological stations have only recently [1991] been established in the area and the data should be considered, only, as a guide to climate conditions." They briefly outline the climate of this tropical locality, which is summarised as follows: "near enough to the equator to be little affected by day length (one hour's difference), but far enough south to experience marked seasonal changes. The warm, austral summer [minimummaximum temperature $22-28^{\circ} \mathrm{C}$ ] commences in September and ends in February, but not until December to February [mean maximum rainfall $1,258 \mathrm{~mm}$ ] do rains reach their peak. The cooler, austral winter [minimum-maximum temperature $16-27^{\circ} \mathrm{C}$ ] begins in March and ends in August, during which rainfall [mean maximum rainfall $224 \mathrm{~mm}$ ] is considerably reduced."

In December 2004, two small sections of branch were found lying on the ground beneath a mature tree of Pithecillobium scalare Griseb. (family Mimosaceae). The ends of both sections appeared to have been severed from the inside; by inference, cut by a larva. One piece of branch was retained for further observation. Almost exactly a year later $\left(8^{\text {th }}\right.$ December 2005) a cerambycid emerged, Phoebemima ensifera, of the tribe Hemilophini. Girdling has been referred to by Linsley (1961): "A very characteristic mode of feeding is found among the twig girdlers and pruners .... the twig is girdled by the adult beetles ... or by the larva of many of the Elaphidionini."

Regular visits were made to the Pithecillobium without 
finding, what we now knew to be, further pupal chambers. However, on $11^{\text {th }}$ January 2006 another species of Mimosaceae [Samanea tubulosa (Benth.), known locally as "Penoco"] was found with a girdled branch and on the ground a pupal chamber similar to that cut by $P$. ensifera. Forty-five weeks later ( $23^{\text {rd }}$ November 2006) an adult of this species emerged from it.

From January 2006 to September 2007 we have made observations of host plants in the field, and longitudinally sectioned branch parts and pupal chambers containing live larvae and pupae (kept in plastic vivaria) under simple (some humidity control) laboratory conditions. Using the data collected from 18 cases of girdled Samanea branches the following outline of the life cycle of Phoebemima ensifera is presented, together with photographs of the host plant, girdled branches, larva, pupa, and adults.

Material examined. Bolivia, Department of Santa Cruz, Hotel Flora \& Fauna, $17^{\circ} 29^{\prime} 96^{\prime \prime} \mathrm{S} / 63^{\circ} 39^{\prime} 13^{\prime \prime} \mathrm{W}, 430 \mathrm{~m}, 5 \mathrm{~km}$ SE of Buena Vista. 1 female, 8.XII.2005, R. Clarke/S. Zamalloa col., emerged from internally girdled "Juno" branch (MZSP). The following with same data, different host plant: 1 female, 23.XI.2006, emerged from "Penoco" branch, first cut 11.I.2006, second cut 15.I.2006 (RCSZ); 1 female, 7.II.2007, emerged from "Penoco" branch, first cut 13.III.2006, second cut 16.III.2006 (RCSZ); 1 fifth instar larva, 1.VI.2007, from pupal chamber (6 cm long x 1,9 cm diameter) on ground below "Penoco" sapling, photographed and preserved in alcohol (MZSP); 1 pupa, 28.VIII.2007, from pupal chamber $(7,0 \times 1,7 \mathrm{~cm}$.) on ground below "Penoco" sapling, 11.VII.2007, photographed and preserved in alcohol (MZSP).

\section{RESULTS}

Adult Behaviour. Adults come to light in October and November; three examples bred from cut branches kept under laboratory conditions emerged in November (2006), December (2005), and February (2007). It is probable that mating and oviposition take place shortly after emergence. All the Samanea selected for oviposition were small 2-3 metre-high plants (Fig. 1); albeit mature trees offered a multitude of branches of equal size, none had been girdled. Branches that were longitudinally sectioned indicated the absence of competing larvae; whether due to larval cannibalism by early instars (less likely) or selective oviposition (more likely) could not be resolved. There was no evidence that females prepared oviposition sites with their mandibles, although the bark of Samanea is moderately rough and small egg scars could have been overlooked, it seems more likely that the eggs are deposited directly below the soft, corky bark. Eggs were usually laid within the basal third of each branch and, in all cases, eggs appeared to have been laid apically to the part of the branch eventually utilised for the pupal chamber.

Larval Behaviour. Exactly when the $1^{\text {st }}$ to $3^{\text {rd }}$ instar larvae change from one instar to another is not known, but the change from $3^{\text {rd }}$ to ${ }^{\text {th }}$ probably takes place after 3-4 months, shortly before the larva starts preparations for the severance of the pupal chamber, and the change from $4^{\text {th }}$ to $5^{\text {th }}$ instar always takes place inside the pupal chamber after 9-10 months, 2-4 weeks before pupation. As set out here larval activity may
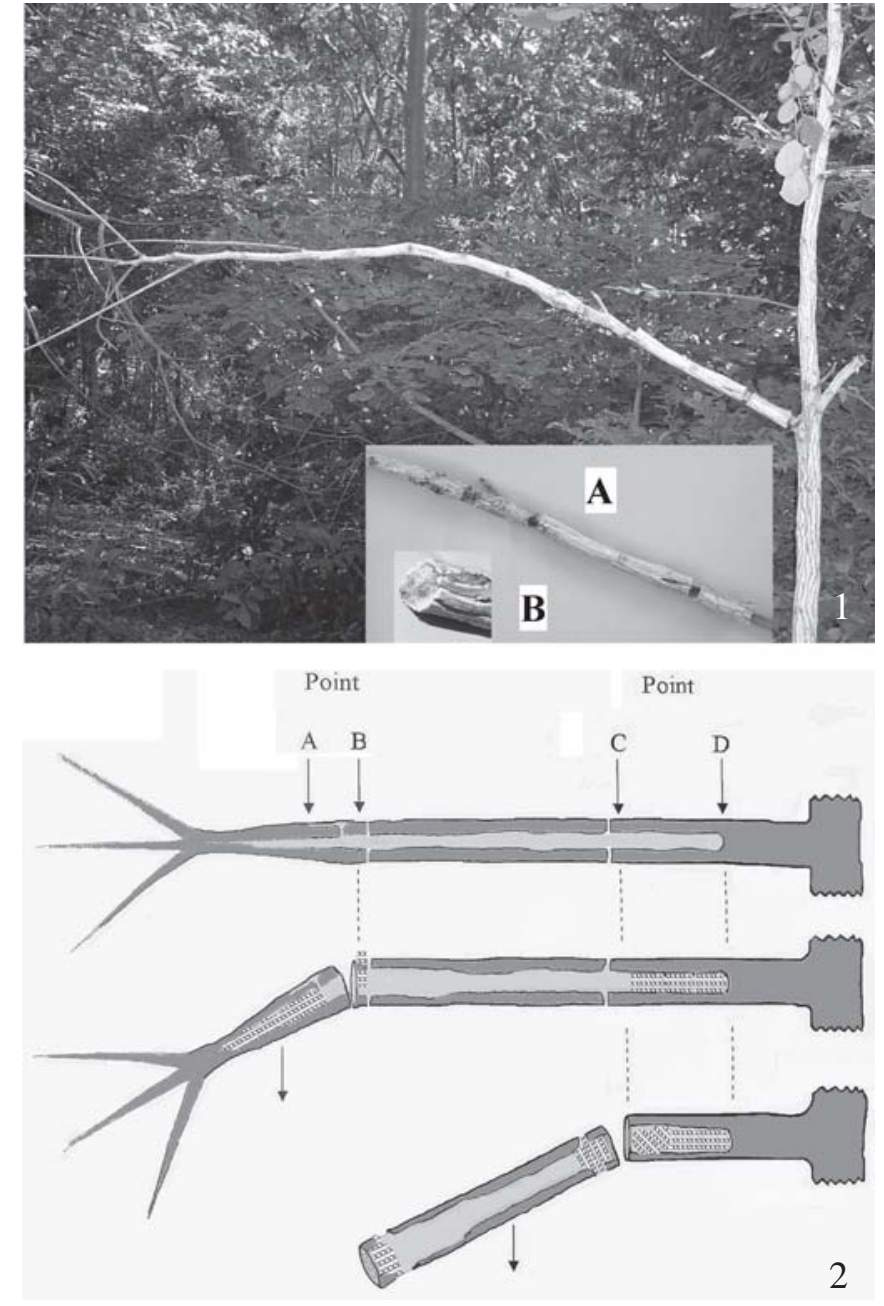

Figs. 1-2. Branch girdling by larvae of Phoebemima ensifera Tippmann. 1, Small Penoco tree (right) with reassembled branch severed by two $P$. ensifera larvae; A. detail reassembled branch; B. detail severed tip of pupal chamber; 2, Schematised larval activity of $P$. ensifera in Penoco branch. Top: $1^{\text {st }}$ to $3^{\text {rd }}$ instar work. Centre: $3^{\text {rd }} / 4^{\text {th }}$ instar work. Bottom: $4^{\text {th }}$ instar work.

appear to be unnaturally complicated, and so it has to be, for the development of the larvae of P. ensifera requires combination of a number of behavioural adaptations: i) the larva has to keep its burrow clear of frass and other woody particles that cannot be consumed; ii) the apodous larva (inside its tight-fitting burrow) must turn itself around on, at least, three occasions to account for observed activity; and iii) on two occasions the larva must make preparations to sever the branch without danger of exposing itself to the world outside. Furthermore, after severing its pupal chamber from the parent plant, the $4 / 5^{\text {th }}$ instars have to complete their growth, over a period of 5-10 months, trapped within a short piece of branch which may be as small as 2,5 cm in length and $1,4 \mathrm{~cm}$ diameter.

Since branches bored by Phoebemima larvae remain in green and leafy condition this stratagem may be related to the defensive behaviour of the plant (which produce considerable 
quantities of gummy sap at the site of wounded tissues) or, may be, evasion of predatory mites, ants, woodpeckers and monkeys, all of which are very active during this time (the beginning of the dry season).

Larval Development (Figs. 1-7). First instar larvae hatch from the egg at point A (Fig. 2, top) and start feeding subcortically, the $2^{\text {nd }}$ instar moving a short distance distally $(1-4 \mathrm{~cm})$ before entering the heartwood between points $A$ and B.

The $2 / 3^{\text {rd }}$ instar, feeding on the heartwood moves up and, then, down the stem to point $\mathrm{B}(3-7 \mathrm{~cm}$ from point $\mathrm{A})$ where it chews two small holes (the frass apertures, figs. 4, 5) opposite each other, and through which it ejects frass and slivers of fibre to the outside. After completion of these the $2 / 3^{\text {rd }}$ instar continues to move down the branch, feeding and backing up to eject frass at point $B$, until it reaches point $C(3-10 \mathrm{~cm}$ from point $\mathrm{B})$. Here it prepares further frass apertures.

From point $\mathrm{C}$ the $3^{\text {rd }}$ instar moves further down the branch, feeding and backing up to eject frass at point $C$, until it reaches point $\mathrm{D}(9,5-16,0 \mathrm{~cm}$ from point $\mathrm{A})$. Here the $3^{\text {rd }}$ instar, having reached the end of its burrow, backs up for a short distance (2$5 \mathrm{~cm}$ ) to return to point $C$, where it furthers its preparations to sever the branch several weeks later. These preparations consist of: i) chewing a transverse channel ( $0,3 \mathrm{~cm}$ diameter) connecting the frass apertures which, when the time comes to sever the branch, will be enlarged and filled with frass by the $4^{\text {th }}$ instar to serve as a plug (the T-plug) sealing its burrow from the world outside; and ii) preliminary work to sever the branch by chewing away the wood as far as the phloem (which shrinks, to leave a depressed ring visible on the outer surface of the branch).

After the preparations at point $C$ have been made the $3 / 4^{\text {th }}$ instar larva backs up to point $\mathrm{B}$, further enlarging its burrow on the way. At point $\mathrm{B}$ the $4^{\text {th }}$ instar repeats the preparations (as at point $\mathrm{C}$ ) and enlarges the upper part of its burrow (between points B and C) to form the pupal cell; much of the detritus produced during these operations will be stuffed into the apex of its burrow or ejected to the outside through the frass apertures made earlier. The larva now makes the final preparations to, nearly, sever the branch by reducing the thickness of the phloem to a thin, narrow ring and tightly plugging its burrow (at point B) with fibres to prevent the ingress of predators. Now the larva must wait until gravity and climate (rain and wind) combine to sever the apex of the branch (35-97 cm length) from the pupal chamber (Fig. 2, centre).

Once the branch has been severed at point $\mathrm{B}$ the $4^{\text {th }}$ instar turns around and returns to point $\mathrm{C}$, where it makes the final preparations for the second cut (partly prepared earlier) by reducing the phloem further and filling the lower section of, and the opening to, its burrow with fibres. Again, the larva must wait for gravity and climate to sever its pupal chamber (Fig. 2, bottom) from the parent plant (2-9 days after the first cut).
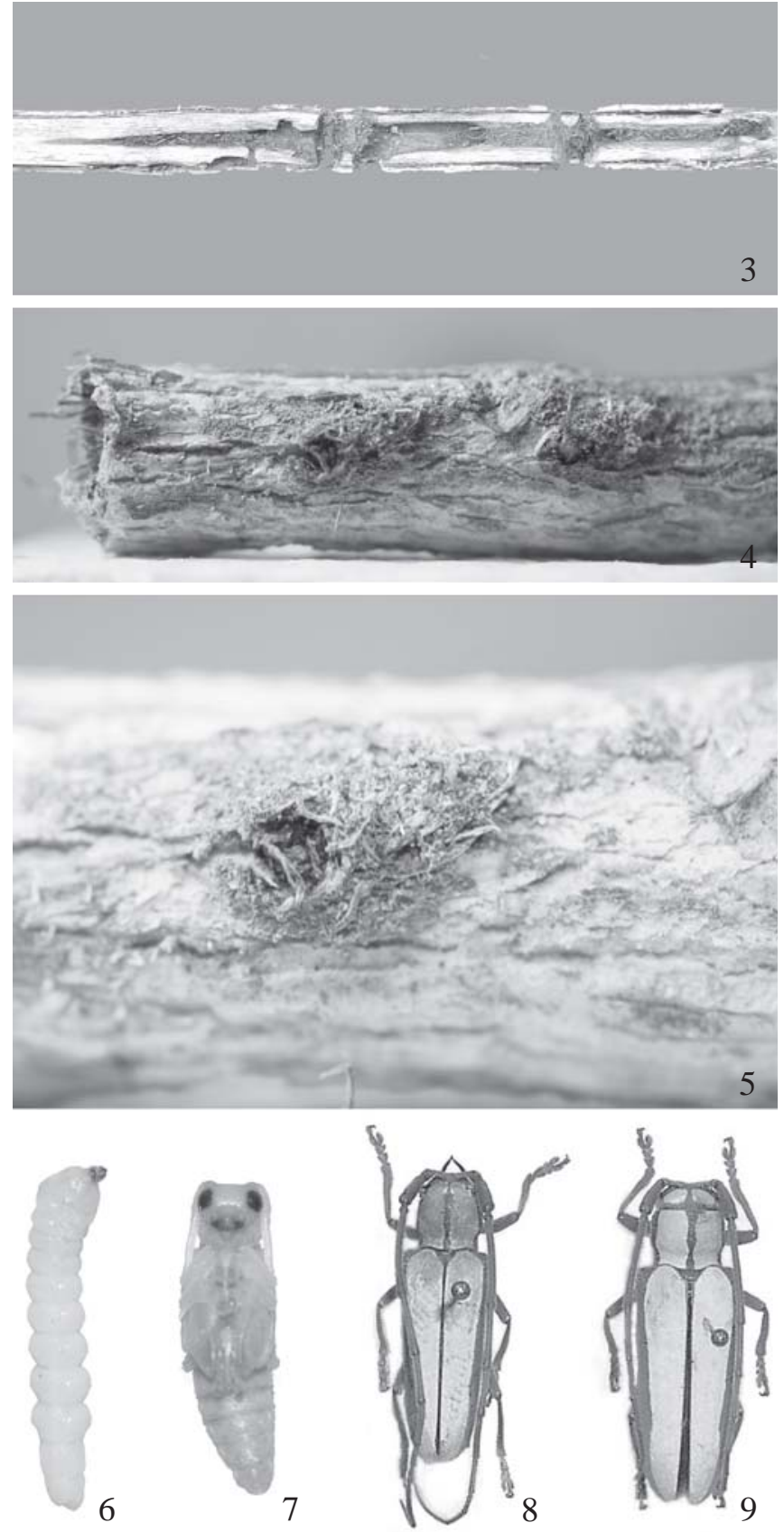

Figs. 3-9. Life cycle of Phoebemima ensifera Tippmann. 3, Sectioned Penoco branch showing work of $P$. ensifera larva; 4, Apex of pupal chamber showing position of frass aperture; 5, Detail of frass aperture; 6 , . ensifera $5^{\text {th }}$ instar larva $(38 \mathrm{~mm}) ; 7$, P. ensifera pupa $(23 \mathrm{~mm}) ; 8$, $P$. ensifera adult male $(17 \mathrm{~mm}) ; 9$, P. ensifera adult female $(19 \mathrm{~mm})$.

Now, lying on the ground, this small section of branch (2,5-8,2 cm long, 1,4-2,8 cm diameter) will be home to the larva for up to ten months. Once the pupal chamber has fallen to the ground the 4th instar larva continues to feed by enlarging its burrow and pupal cell (which is directly adjacent to the Tplug) and stuffing the detritus towards the bottom of its chamber. At some time the larva returns to the pupal cell (where it now makes its final turn, with its head once again pointing towards point $\mathrm{B}$ ) to initiate a short period of increased activity: 
ejecting large quantities of detritus through the frass apertures at point $\mathrm{B}$. This is followed by a long inactive period but, by August, the $4^{\text {th }}$ instar larva will have changed into the $5^{\text {th }}$ instar (Fig. 6), wedging its shed skin against the frass filling the lower part of the pupal chamber.

The $5^{\text {th }}$ instar, which appears to be less active than other stages, feeds in a desultory manner before closing the apical frass apertures. By late August to mid September the $5^{\text {th }}$ instar ceases its movements and, lying within the pupal cell, pupates (Fig. 7). 10-20 days after pupation freshly emerged adults were observed in their pupal cells and their life cycle completed by the emergence of adults (Figs. 8,9) in October-November, at the start of the summer rains. [Note: nearly all of these adults were liberated after emergence.]

Behavioural Variations. The following tree species (all of the family Mimosaceae) have been selected for oviposition; the number of girdled branches is shown in brackets:

Host Plant 1 (4 exx.): "Juno" Pithecillobium scalare Griseb. Host Plant 2 (1 ex.): "Pacay del Rio" Inga sp. indet.

Host Plant 3 (5 exx.): "Pacay verde" Inga sp. indet.

Host Plant 4 (2 exx.): "Jebio" Albizia niopoides (Benth)

Host Plant 5 (18 exx.): "Penoco" Samanea tubulosa (Benth.)

Observations have shown that 2-3 larva may complete their development in a single branch (as in fig. 1) or, when the tree is very young, in the trunk itself. When the branch is small larvae may feed on more of the apical and basal portions than normal; and, conversely, when the diameter of the branch is large, or when the wood of the host plant is harder (as in Jebio, Juno and Pacay), the larvae may restrict their feeding to that part of the branch destined for the pupal chamber. It sometimes happens that the branch/trunk develops splits in the cortex and these are quickly stuffed with fibre by the larva; occasionally obviating the need to prepare frass apertures.

Acknowledgements. To Dra. Maria Helena Galileo, Museu de Ciências Naturais, Porto Alegre, for greatly improving the draft manuscript and Dr. Ubirajara Martins, Museu de Zoologia, São Paulo, who encouraged us to pursue this interesting discovery. Two plant experts: Dr. Michael Nee, Curator of the New York Botanical Gardens, for identifying the plants and Señor Ruperto Vargas, for their local names.

\section{REFERENCES}

Bondar, G. 1938. Notas entomologicas da Bahia. III. Revista de Entomología 9: 441-449.

Clarke, R. O. S. \& F. Sagot. 1996. A Guide to the World's Best Bird-Watching Place: Amboró Protected Area, Bolivia. Santa Cruz, Armonia. 1-100.

Di Iorio, O. R.; H. A. Cordo; G. A. Logarzo \& D. E. Gandolfo, 1998 Cerambycidae (Coleoptera) root and stem borers in living plants from Argentina: a bibliographical review and new host plant records. Giornale Italiano di Entomologia 9: 73-95.

Duffy, E. A. J. 1960. A monograph of the immature stages of Neotropical timber beetles (Cerambycidae). Londres, British Museum (Natural History). vii, 327 p.

Linsley, E. G. 1961. The Cerambycidae of North America. Part I. Introduction. University of California Publications in Entomology 18: 1-97.

Molinari, O. C. 1942. Entomología Agrícola. Identificación y control de insectos y otros animales dañinos o útiles a las plantas. San Juan. 571 p.

Monné, M. A. \& F. T. Hovore, 2006. Checklist of the Cerambycidae, or longhorned wood-boring beetles, of the Western Hemisphere. Rancho Dominguez, BioQuip. 349 p.

Monné, A. M. 2002. Catalogue of the Neotropical Cerambycidae (Coleoptera) with known host plant. Part IV: Subfamily Lamiinae, Tribes Batocerini to Xenofreini. Publicações Avulsas do Museu Nacional 94: 1-92.

Received 07/07/2008; accepted 23/10/2008 